\title{
p53-independent structure-activity relationships of 3-ring mesogenic compounds' activity as cytotoxic effects against human non-small cell lung cancer lines
}

Saori Fukushi ${ }^{1}$, Hironori Yoshino ${ }^{2}$, Atsushi Yoshizawa ${ }^{1}$ and Ikuo Kashiwakura2 ${ }^{2^{*}}$

\begin{abstract}
Background: We recently demonstrated the cytotoxicity of liquid crystal precursors (hereafter referred to as "mesogenic compounds") in the human non-small cell lung cancer (NSCLC) cell line A549 which carry wild-type p53. p53 mutations are observed in $50 \%$ of NSCLC and contribute to their resistance to chemotherapy. To develop more effective and cancer-specific agents, in this study, we investigated the structure-activity relationships of mesogenic compounds with cytotoxic effects against multiple NSCLC cells.

Methods: The pharmacological effects of mesogenic compounds were examined in human NSCLC cells (A549, LU99, EBC-1, and H1299) and normal WI-38 human fibroblast. Analyses of the cell cycle, cell-death induction, and capsases expression were performed.

Results: The 3-ring compounds possessing terminal alkyl and hydroxyl groups (compounds C1-C5) showed cytotoxicity in NSCLC cells regardless of the p53 status. The compounds C1 and C3, which possess a pyrimidine at the center of the core, induced G2/M arrest, while the compounds without a pyrimidine (C2, C4, and C5) caused G1 arrest; all compounds produced caspase-mediated cell death. These events occurred in a p53-independent manner. Furthermore, it was suggested that compounds induced cell death through p53-independent DNA damagesignaling pathway. Compounds C2, C4, and C5 did not show strong cytotoxicity in Wl-38 cells, whereas C1 and C3 did. However, the cytotoxicity of compound C1 against WI-38 cells was improved by modulating the terminal alkyl chain lengths of the compound.

Conclusions: We showed the p53-indepdent structure-activity relationships of mesogenic compounds related to the cytotoxic effects. These structure-activity relationships will be helpful in the development of more effective and cancer-specific agents.
\end{abstract}

Keywords: Non-small cell lung cancer, Structure-activity relationship, p53, G2/M arrest, G1 arrest, Cell death, Caspase, DNA damage-signaling pathway, Alkyl chain length

\footnotetext{
* Correspondence: ikashi@hirosaki-u.ac.jp

${ }^{2}$ Department of Radiation Science, Hirosaki University Graduate School of

Health Sciences, 66-1 Hon-cho, Hirosaki, Aomori 036-8564, Japan

Full list of author information is available at the end of the article
} 


\section{Background}

Lung cancer is the leading cause of cancer-related death over the world among both men and women. Non-small cell lung cancer (NSCLC) accounts for $85 \%$ of all cases of lung cancer, and the overall 5-year survival rate of patients with NSCLC remains lower than $15 \%$ [1]. To improve the survival of patients with NSCLC, anticancer agents such as molecular-targeted drugs [2-4] are under development. However, few drug therapies lead to complete recovery in patients with NSCLC. Therefore, development of more effective anticancer drugs is essential for the treatment of NSCLC.

p53 is a tumor suppressor gene that plays critical roles in cellular responses, such as cell cycle arrest and apoptosis, after exposure to various stresses including DNA damage [5]. In response to DNA damage such as ionizing radiation, ataxia-telangiectasia mutated/ataxiatelangiectasia and Rad-3-related (ATM/ATR), which is a DNA damage sensor, stabilizes and activates p53; activated p53 then transcriptionally regulates apoptosisrelated genes as well as cell cycle arrest-related genes [6]. In addition to transcriptional activity, p53 can activate the intrinsic mitochondrial-mediated pathway of apoptosis in a transcriptional-independent manner by interacting with B-cell lymphoma file family members [7]. The importance of p53 in cancer treatment has been shown in many studies [8-11]. For example, the loss of p53 function in lung cancers results in resistance to not only radiation but also molecularly targeted drugs such as epidermal growth factor receptor inhibitors [10, 11]. This is at least in part due to the impairment of p53mediated apoptosis induction $[12,13]$. Since p53 mutations are observed in $50 \%$ of NSCLC [14] and contribute to their resistance to chemotherapy [15], drugs exerting anticancer effects independent of p53 are required for NSCLC treatment.

Liquid crystals (LCs) are compounds that exist in a state of matter between liquid and crystalline phases and can be characterized by the loss of positional order while maintaining orientational order [16]. Lyotropic LCs can be found in the LC phase depending on both the temperature and the concentration of LC molecules in a solvent; these compounds are observed in biological structures such as cell membranes, which are comprised of a lamellar bilayer of mesophases of phospholipids, glycolipids, and cholesterol. Some studies have focused on the structural affinities of cell membranes for LCs and have assessed the application of LCs as drugdelivery systems $[17,18]$. In previous studies, we investigated the cytotoxicity of LC compounds and their precursors (mesogenic compounds) [19-23] and showed that some amphiphilic LC compounds, such as cyanobiphenyl derivatives with terminal hydroxyl moieties, moderately suppressed cell growth in the NSCLC cell line
A549 [20]. Furthermore, an amphiphilic LC precursor with three aromatic rings dramatically suppressed cell growth and induced apoptosis in A549 cells, but it also showed low cyototoxicity in normal WI-38 fibroblast cells [22]. To explore and further develop the potential application of LC precursors as anticancer drugs, we investigated the structure-activity relationships of various LC precursors and their analogs and examined their cytotoxic effects in multiple NSCLC cell lines, both with and without p53. Here we demonstrated that not only the 3-ring structure with terminal alkyl and hydroxyl groups but also the alkyl chain lengths are structurally important for the cytotoxic effects of mesogenic compounds against human NSCLC cells. Furthermore, we showed the p53-indepdent structure-activity relationships of mesogenic compounds related to the cytotoxic effects.

\section{Methods \\ Compounds}

Test compounds (Fig. 1a) were dissolved in dimethyl sulfoxide (DMSO; Sigma-Aldrich, St Louis, MO, USA) at $10 \mathrm{mM}$ concentration. 2-(4-Hexyloxyphenyl)-5-(4hydroxyphenyl)pyrimidine $(\mathrm{C} 1)$ and its homologous series (as shown in Fig. 1f), 2-(4-hexylphenyl)-5-(4hydroxyphenyl)pyrimidine (C3), 2-(4-hydroxyphenyl)-5hexylpyrimidine (C6), and 2,5-bis(4-hexyloxyphenyl) pyrimidine $(\mathrm{C} 7)$ were purchased from Midori Kagaku Co., Ltd. (Tokyo, Japan). 2-[4-(Hexyloxy)phenyl]-5-(4hydroxyphenyl)pyridine (C2), 2-[4-(4-hydroxyphenyl) phenyl]-5-hexylpyrimidine (C4), and 2-[4-(4-hydroxyphenyl) phenyl]-5-hexylpyridine (C5) were provided from Japan Energy Corporation (Tokyo, Japan).

The octanol-water coefficient $(\log \mathrm{P})$ values were calculated using ChemDraw software (Perkin Elmer Informatics).

\section{Reagents}

Propidium iodide (PI) and caffeine were purchased from Sigma-Aldrich (St. Louis, MO, USA). Z-Val-Ala-Asp (OMe)- $\mathrm{CH}_{2} \mathrm{~F}$ (Z-VAD-fmk) was purchased from Peptide Institute, Inc. (Osaka, Japan). The fluorescein isothiocyanate (FITC)-labeled monoclonal antibody anti-human cluster of differentiation 95 (CD95-FITC) was purchased from BioLegend (San Diego, CA, USA). FITC-conjugated antimouse $\operatorname{IgG}_{1}$ antibody was purchased from BeckmanCoulter (Fullerton, CA, USA). Kp7-6 was purchased from EMD Millipore (Darmstadt, Germany). $\beta$-actin antibody (\#4967), p53 antibody (\#9282), cyclin B1 antibody (\#4135), phospho-cdc2 (Tyr15) antibody (\#9111), phospho-Histone H3 (Ser10) antibody (\#3377), caspase-3 antibody (\#9662), caspase-8 antibody (\#9746), caspase-9 antibody (\#9502), phosphor-ATM (Ser1981) (D25E5) antibody (\#13050), anti-rabbit IgG horse radish peroxidase (HRP)-linked antibody (\#7074), and anti-mouse IgG HRP-linked antibody 


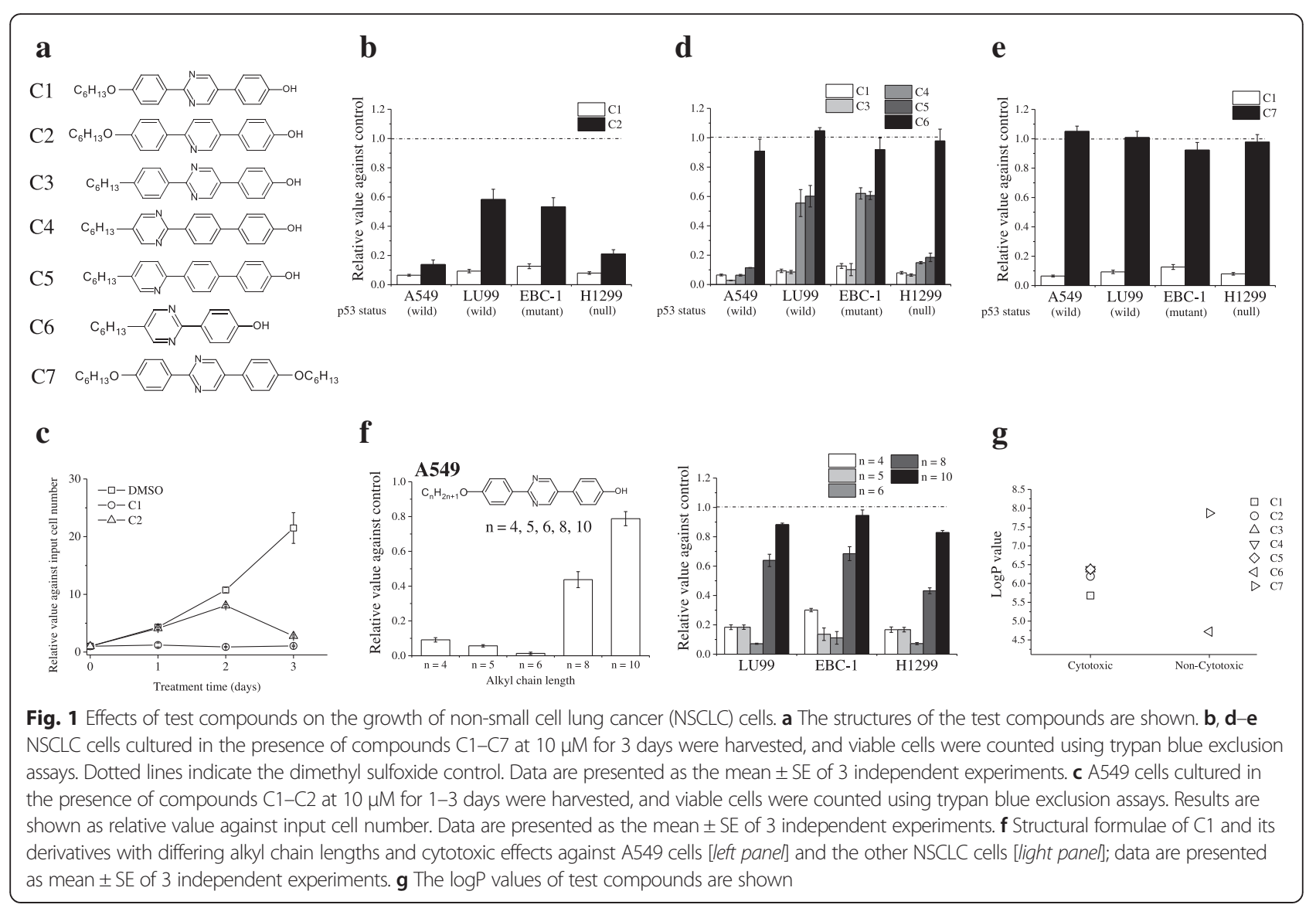

(\#7076), Alexa Fluor ${ }^{\circledR}$ 488-conjugated goat anti-rabbit IgG (\#4412) were purchased from Cell Signaling Technology Japan, K.K. (Tokyo, Japan). Goat anti-actin polyclonal antibody (sc-1615), rabbit anti-p21 polyclonal antibody (sc-756), and HRP-conjugated donkey anti-goat IgG antibody (sc-2056) were purchased from Santa Cruz Biotechnology, Inc. (Santa Cruz, CA, USA). For knockdown of p53, Ambion's Silencer ${ }^{\ominus}$ select pre-designed siRNA (ID: s606) and Silencer ${ }^{\oplus}$ select negative control 1 were purchased from Life Technologies Corporation (Carlsbad, CA, USA).

\section{Cell culture and treatment}

A549 (p53 wild type) human lung cancer cells and WI38 normal human fibroblasts (embryonic fibroblast, lung-derived cell line) were purchased from the Riken Bio-Resource Center (Tsukuba, Japan). LU99 (p53 wild type) and EBC-1 (p53 mutant) human lung carcinoma cells were purchased from the JCRB Cell Bank (Osaka, Japan). H1299 (p53-null) human lung carcinoma cells were purchased from the American Type Culture Collection (ATCC, Manassas, VA, USA). The A549 cells were maintained in Dulbecco's modified Eagle's medium (Sigma-Aldrich) supplemented with $1 \%$ penicillin/ streptomycin $\left(\mathrm{GIBCO}^{\circ}\right.$; Invitrogen, CA, USA) and $10 \%$ heat-inactivated fetal bovine serum (FBS; Japan Bioserum Co., Ltd., Japan) at $37{ }^{\circ} \mathrm{C}$ in a humidified atmosphere containing $5 \% \mathrm{CO}_{2}$. WI-38 and EBC-1 cells were cultured in Eagle's minimum essential medium (Sigma-Aldrich) supplemented with $1 \%$ penicillin/streptomycin and $10 \%$ heat-inactivated FBS at $37{ }^{\circ} \mathrm{C}$ in a humidified atmosphere containing $5 \% \mathrm{CO}_{2}$. The LU99 and $\mathrm{H} 1299$ cells were maintained in RPMI1640 (GIBCO $\left.{ }^{\circ}\right)$ supplemented with $1 \%$ penicillin/streptomycin and $10 \%$ heat-inactivated FBS at $37{ }^{\circ} \mathrm{C}$ in a humidified atmosphere containing $5 \% \mathrm{CO}_{2}$.

NSCLC cell lines $\left(6.0 \times 10^{4}\right.$ cells $)$ or WI-38 cells $(6.0 \times$ $10^{4}$ cells) were seeded onto $35-\mathrm{mm}$ culture dishes (Iwaki, Chiba, Japan) and were cultured overnight to allow adherence to the dish. On the next day, compounds were added to the culture medium (at a final concentration of $10 \mu \mathrm{M})$ and cells were cultured for 3 days. For cell cycle analysis, NSCLC cell lines $\left(1.2 \times 10^{5}\right.$ cells $)$ were seeded onto 60-mm culture dishes (Iwaki, Chiba, Japan). Cells were subsequently harvested using $0.1 \%$ trypsinethylenediaminetetraacetic acid (Gibco ${ }^{\circ}$; Invitrogen), and viable cells were counted using the trypan blue dye exclusion method. Because LU99 cells were loosely adhered to the dish, they were harvested without the use of trypsin-ethylenediaminetetraacetic acid. Cell survival was expressed as the rate of viable cell number against 
the vehicle (DMSO)-treated cells. No significant cytotoxicty of DMSO treatment was observed in any of the cell lines.

\section{siRNA transfection}

A549 cells were transfected with p53-targeting siRNA (p53 siRNA) or control siRNA using Lipofectamine RNAiMAX (Invitrogen) according to the manufacture's recommended protocol. The final concentration of siRNA was $5 \mathrm{nM}$. After $24 \mathrm{~h}$ incubation, the transfected cells were harvested and used for subsequent analyses.

\section{Cell cycle analysis}

The cells treated with compounds were harvested and fixed in $70 \%$ ethanol overnight at $-20{ }^{\circ} \mathrm{C}$. The fixed cells were washed with $\mathrm{Ca}^{(2+)}$ - and $\mathrm{Mg}^{(2+)}$ - free phosphatebuffered saline $[\mathrm{PBS}(-)]$ and then treated with RNase A $(200 \mu \mathrm{g} / \mathrm{mL})$ at $37{ }^{\circ} \mathrm{C}$ for $30 \mathrm{~min}$ to hydrolyze RNA. After treatment, the cells were washed with $\mathrm{PBS}(-)$ and stained with PI $(30 \mu \mathrm{g} / \mathrm{mL})$ for $30 \mathrm{~min}$ in the dark. Then, the cells were filtered with cell strainer (BD Falcon ${ }^{\mathrm{Tw}}$, Franklin Lakes, NJ, USA). The cell-cycle distribution was analyzed by flow cytometry (Cytomics FC500, BeckmanCoulter).

\section{SDS-PAGE and western blotting}

SDS-PAGE and western blotting were performed as previously described [24]. The following primary antibodies were used: rabbit anti-p53 antibody (1:4000), rabbit antip21 polyclonal antibody (1:4000), rabbit anti-phosphoHistone H3 antibody (1:3000), rabbit anti-phospho-cdc2 antibody (1:3000), mouse anti-cyclin B1 antibody (1:3000), rabbit anti-caspase-3 antibody (1:3000), mouse anticaspase- 8 antibody (1:3000), rabbit anti-caspase- 9 antibody (1:3000), rabbit anti- $\beta$-actin antibody (1:5000), or goat anti-actin polyclonal antibody (1:5000). Each primary antibody was diluted in Can Get Signal ${ }^{\circ}$ Immunoreaction Enhancer Solution 1 (TOYOBO, Co., Ltd, Osaka, Japan). The following secondary were used: HRP-linked antirabbit IgG antibody (1:10000), HRP-linked anti-mouse IgG antibody (1:10000), or HRP-conjugated donkey antigoat IgG antibody (1:10000). Each secondary antibody was diluted in Can Get Signal ${ }^{\circ}$ Immunoreaction Enhancer Solution 2 (TOYOBO). The antigens were visualized by the ECL Prime Western Blotting Detection System (GE Healthcare). Blot stripping was performed using Stripping Solution (Wako Pure Chemical Industries).

\section{In vitro irradiation}

Radiation exposures $(150 \mathrm{kVp}, 20 \mathrm{~mA}, 0.5-\mathrm{mm} \mathrm{Al}$ and 0.3-mm Cu filters) were performed using an X-ray generator (MBR-1520R-3, Hitachi Medical Corporation, Tokyo, Japan) at a distance of $45 \mathrm{~cm}$ from the focus at a dose rate of $1.04 \mathrm{~Gy} / \mathrm{min}$.

\section{Analysis of apoptosis}

Cell death was analyzed by annexin V-FITC (BioLegend) and PI staining according to the manufacturer's instructions. In brief, the cells treated with each compound were harvested, washed, and suspended in annexin $\mathrm{V}$ Binding Buffer (BioLegend). The annexin V-FITC $(2.5 \mu \mathrm{g} / \mathrm{mL})$ and PI solution $(50 \mu \mathrm{g} / \mathrm{mL})$ were added to the cell suspension and incubated for $15 \mathrm{~min}$ at room temperature in the dark. Then, the apoptotic cells were analyzed by flow cytometry (Cytomics FC500, Beckman-Coulter). In the annexin V/PI quadrant gating, annexin $\mathrm{V}(-) / \mathrm{PI}(-)$, annexin $\mathrm{V}(+) / \mathrm{PI}(-)$, and annexin $\mathrm{V}(+) / \mathrm{PI}(+)$ were used to identify the fraction of viable cells, early apoptotic cells, and late apoptotic/necrotic cells, respectively.

\section{Detection of active caspase-3}

An FITC-conjugated monoclonal active caspase-3 antibody apoptosis kit (BD Biosciences, San Diego, CA, USA) was used to detect active caspase-3 according to the manufacturer's instructions. In brief, the cells treated with each compound were harvested, washed, and suspended in Cytofix/Cytoperm ${ }^{\text {Tw }}$ buffer. The cell suspensions were placed on ice for $20 \mathrm{~min}$ and washed with Perm/Wash ${ }^{\text {tws }}$. Then, the cells were resuspended in Perm/Wash ${ }^{\text {Tw }}$ buffer containing $10 \%$ FITC-conjugated caspase-3 antibody and incubated for $30 \mathrm{~min}$ at room temperature in the dark. The cells were washed and analyzed by flow cytometry.

\section{Treatment with various inhibitors}

Cells were preincubated with each inhibitor, $50 \mu \mathrm{M} \mathrm{Z-}$ VAD-fmk (a pan-caspase inhibitor), $1 \mathrm{mM} \mathrm{kp7-6} \mathrm{(Fas/}$ Fas ligand antagonist), or $2 \mathrm{mM}$ caffeine (an inhibitor of ATM/ATR) for $1 \mathrm{~h}$, and then test compounds were added to the respective cultures. After culture in the presence of the compounds for 24-72 h, the cells were harvested and viable cells were counted. Subsequently, analyses of cell cycle, cell death (annexin V-FITC and PI staining), or caspase-3 expression were performed as described above.

\section{Analysis of cell surface CD95 (Fas) expression}

Cells treated with compounds were harvested and then washed in PBS(-). Cells were then stained with FITCconjugated $\mathrm{CD} 95$ antibody for $30 \mathrm{~min}$ at $4{ }^{\circ} \mathrm{C}$ in the dark. After staining, cells were washed and analyzed using flow cytometry. Before analysis, $25 \mu \mathrm{g} / \mathrm{ml}$ PI was added to cell suspensions to discriminate dead cells from viable cells. After gating PI negative cells, the fluorescence intensity of CD95 staining was analyzed.

\section{Intracellular phosphorylated-ATM staining}

Intracellular phosphorylated-ATM (Ser1981) expression was analyzed using a flow cytometer. Cells treated with 
compounds were harvested and then washed with PBS(-). The cells were fixed in $4 \%$ formaldehyde (Sigma-Aldrich) for $10 \mathrm{~min}$ at $37^{\circ} \mathrm{C}$. After washing with PBS(-), the cells were permeabilized with $90 \%$ methanol overnight at $-20{ }^{\circ} \mathrm{C}$. After washing with incubation buffer (PBS containing $0.5 \%$ bovine serum albumin), cells were suspended in incubation buffer containing primary phosphorylated-ATM antibody (1:1600) for $1 \mathrm{~h}$ at room temperature. After washing with incubation buffer, cells were stained with Alexa Fluor ${ }^{\circ}$ 488-conjugated antirabbit secondary antibody (1:1000) at room temperature in the dark. As a control, cells were stained with Alexa Fluor ${ }^{\circ}$ 488-conjugated secondary antibody alone. After $30 \mathrm{~min}$, cells were washed with incubation buffer and were analyzed using flow cytometry.

\section{Statistical analysis}

Data are presented as mean $\pm \mathrm{SE}$. Comparisons between control and experimental groups were made using twosided Mann-Whitney's U-test or two-sided Student's ttest depending on the normality of data distributions. Differences were considered significant when $p<0.05$. Excel 2010 software (Microsoft, USA) with the add-in software Statcel 3 [25] was used to perform these statistical analyses.

\section{Results}

\section{Cytotoxic effects of compounds}

We have previously showed that 2-(4-butoxyphenyl)-5(4-hydroxyphenyl) pyrimidine (the compound with 4carbon alkyl chains in Fig. 1f), which is a LC-related compound, dramatically suppresses the growth of A549 cells [22]. Based on this, we developed the mesogenic compounds $\mathrm{C} 1$ and $\mathrm{C} 2$ (Fig. 1a). Although the structural difference between $\mathrm{C} 1$ and $\mathrm{C} 2$ is the presence of a pyrimidine at the center of the core, both of these compounds showed cytotoxicity to all the tested NSCLC cell lines (Fig. 1b). Of note, these cytotoxic effects were independent of p53 status. When the dose-response effects of $\mathrm{C} 1$ and $\mathrm{C} 2$ were examined in A549 cells (Additional file 1: Figure S1), we found that the $50 \%$ inhibitory concentrations $\left(\mathrm{IC}_{50}\right)$ of these compounds were $1.9 \pm$ $0.1 \mu \mathrm{M}$ for $\mathrm{C} 1$ and $2.3 \pm 0.2 \mu \mathrm{M}$ for $\mathrm{C} 2$; the cytotoxic effects of these compounds saturated around $10 \mu \mathrm{M}$. Therefore, a concentration of $10 \mu \mathrm{M}$ was used in subsequent experiments. Furthermore, treatment with $\mathrm{C} 1$ and $\mathrm{C} 2$ at $10 \mu \mathrm{M}$ finally gave similar cytotoxicity, although the time dependence of these effects differed between $\mathrm{C} 1$ and $\mathrm{C} 2$ (Fig. 1c). In brief, $\mathrm{C} 1$ showed a dramatic cytotoxicity already at 1 day, while the strong cytotoxicity of $\mathrm{C} 2$ was observed at 3 day.

To clarify the structure-activity relationship of mesogenic compounds, we first focused on the core structure (Fig. 1d). The presence of an ether linkage between the terminal alkoxyl and the core did not affect cytotoxicity. Compounds $\mathrm{C} 4$ and $\mathrm{C} 5$, which possess a nitrogencontaining $p$-terphenyl link, retained cytotoxicity, although we found that the cytotoxic effects varied depending on the presence and position of the pyrimidine. However, 2-ring compounds failed to show cytotoxicity. These results suggested that $p$-terphenyl is important for cytotoxic effects.

Next, we investigated structure-activity relationships in terms of the terminal alkoxyl and hydroxyl groups (Fig. 1e). Compounds with alkoxyl groups at both ends did not show cytotoxicity despite possessing a $p$-terphenyl. We then investigated whether alkyl chain length modulates cytotoxicity (Fig. 1f). Compound C1, with 6carbon alkyl chains, had the highest cytotoxicity. Compounds with $<6$-carbon alkyl chains $(n=4$ or 5$)$ also dramatically suppressed cell growth, but cytotoxic effects decreased when the alkyl chain length exceeded 6 carbons ( $n=8$ and 10). These findings show that the presence of $p$-terphenyl with terminal alkoxyl and hydroxyl groups is structurally important for cytotoxicity.

As the lipophilicity of each compound contributes to properties such as solubility and permeability through biological membranes [26], we compared each compound's $\log \mathrm{P}$ as an estimate of a compound's overall lipophilicity. As shown in Fig. 1g, the cytotoxic compounds $\mathrm{C} 1-\mathrm{C} 5$ had similar $\log \mathrm{P}$ values (5.68-6.38).

\section{Mesogenic compounds affect cell cycle distribution}

Since anticancer drugs suppress tumor cell growth in part through modulation of the cell cycle, we next investigated the effects of the cytotoxic compounds $\mathrm{C} 1-\mathrm{C} 5$ on the cell cycle distribution of NSCLC cells. As shown in Fig. 2a, the cell cycle kinetics of NSCLC cells treated with $\mathrm{C} 1$ were dramatically different from those treated with $\mathrm{C} 2$. Compounds $\mathrm{C} 1$ and $\mathrm{C} 3$, which have a pyrimidine at the center of the core, induced G2/M arrest (Fig. 2a-b and Additional file 2: Figure S2). In the case of $\mathrm{C} 1, \mathrm{G} 2 / \mathrm{M}$ arrest was induced at 6 and $12 \mathrm{~h}$ in LU99 cells (data not shown), although it was not maintained at $24 \mathrm{~h}$ in this cell line. In contrast, the compounds without a pyrimidine at the center of the core (compounds $\mathrm{C} 2$, C4, and C5) induced G1 cell cycle arrest in A549 and H1299 cells (Fig. 2b). These results indicate that mesogenic compounds carrying $p$-terphenyl with terminal alkoxyl and hydroxyl groups affect cell cycle distribution, and that compounds possessing a pyrimidine at the center of the core induce G2/M arrest regardless of p53 status in NSCLC cells.

Next, to investigate the role of p53 in the G2/M arrest caused by $\mathrm{C} 1$ in p53-wild-type A549 cells, we examined the expression levels of $\mathrm{p} 21$, which is a transcriptional target of p53 and participates in the G2 checkpoint [27]. Although high levels of p21 expression were observed in 


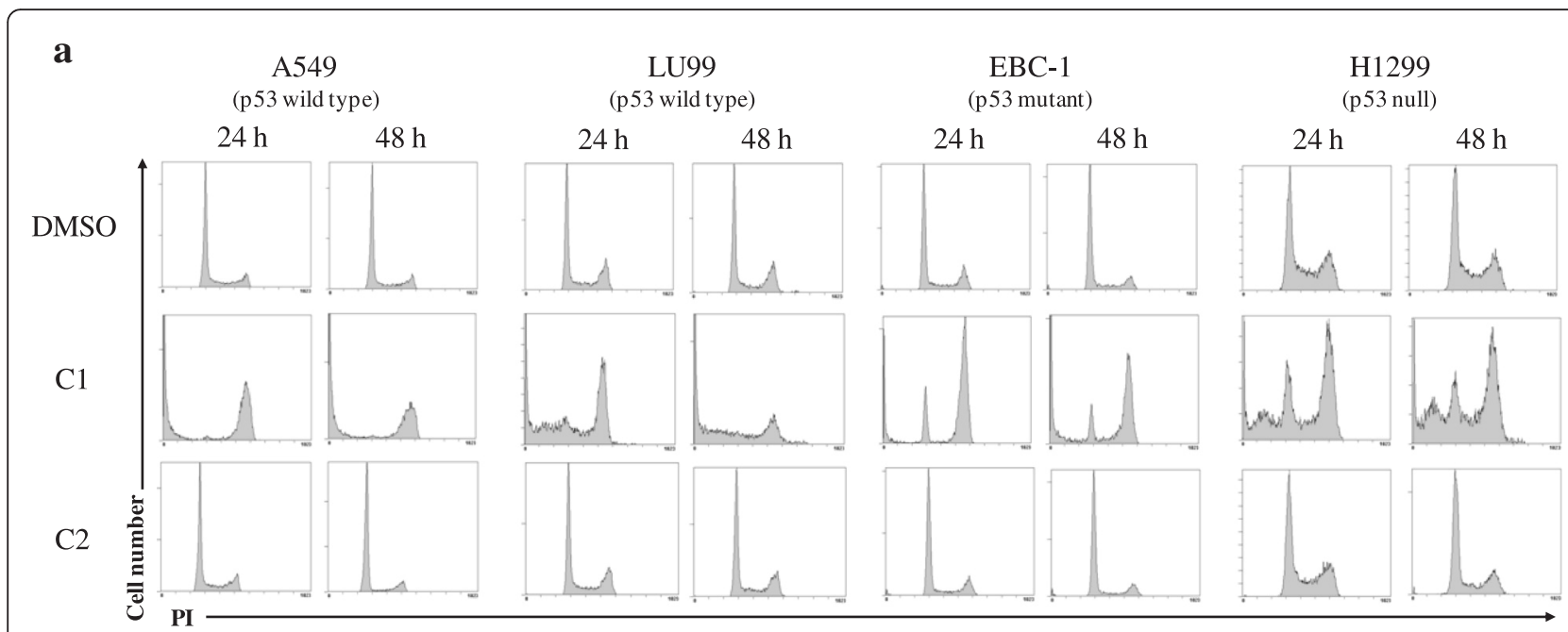

b
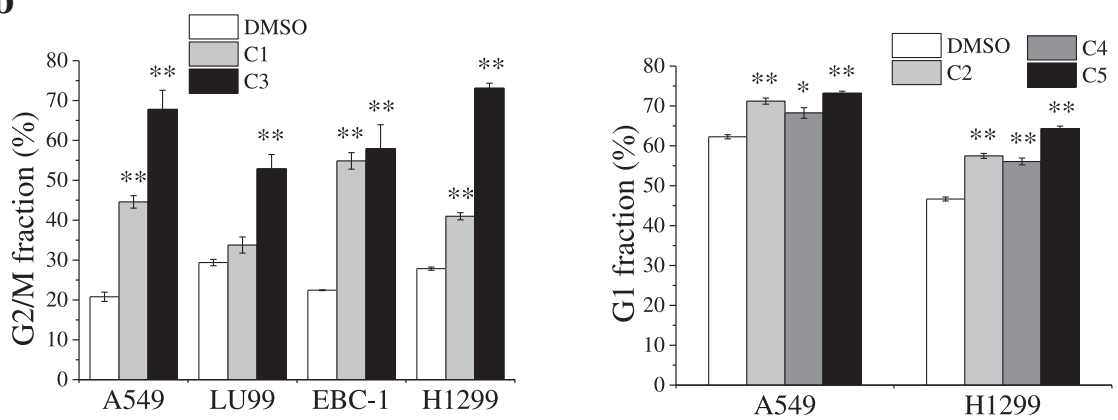

Fig. 2 Effects of test compounds on cell cycle progression. a Non-small cell lung cancer (NSCLC) cells cultured in the presence of test compounds (C1-C2) at $10 \mu \mathrm{M}$ for 24-48 $\mathrm{h}$ were harvested, and then cell cycle profiles were analyzed. Representative histograms of three different experiments are shown. $\mathbf{b}$ NSCLC cells cultured in the presence of test compounds (C1-C5) at $10 \mu \mathrm{M}$ for $24-48 \mathrm{~h}$ were harvested, and then cell cycle profiles were analyzed. Fractions of G2/M at $24 \mathrm{~h}$ in NSCLC cells (A549, LU99, EBC-1, and H1299 cells) [left panel] and G1 at $48 \mathrm{~h}$ in A549 and H1299 cells [light panel] are shown. Data are presented as mean \pm SE of 3 independent experiments. ${ }^{*}$ and ${ }^{* *}$ indicate $p<0.05$ and $p<0.01$ compared with dimethyl sulfoxide control, respectively

irradiated A549 cells, treatment with $\mathrm{C} 1$ did not change the expression of $\mathrm{p} 21$, despite both treatments leading to G2/M arrest (Fig. 3a). In addition, treatment with caffeine, an ATM/ATR inhibitor [28], hardly affected the C1-induced $\mathrm{G} 2 / \mathrm{M}$ arrest, whereas it abrogated the irradiation-induced G2/M arrest (Fig. 3b). These results indicate that ATM/ATR-p53-p21 axis is not involved in the $\mathrm{C} 1$-induced $\mathrm{G} 2 / \mathrm{M}$ arrest. Furthermore, we analyzed the cell cycle distribution of A549 cells transfected with p53-targeting siRNA. Although knockdown of p53 diminished the $\mathrm{C} 1$-induced $\mathrm{p} 53$ expression (Fig. $3 \mathrm{~b}$ ), the increase of $\mathrm{G} 2 / \mathrm{M}$ fraction after $\mathrm{C} 1$ treatment was observed in p53-siRNA trasfected A549 cells (Fig. 3c). These results strongly indicate that $\mathrm{C} 1$ induces $\mathrm{G} 2 / \mathrm{M}$ arrest in A549 cells in a p53-independent manner.

$\mathrm{Cdc} 2 /$ cyclin B1 kinase plays a key role in regulating the G2/M transition [29-31]. The expression of cyclin B1 began to increase during $\mathrm{G} 2$ and peaks in mitosis. On the other hand, dephosphorylation of cdc2 activates the cdc2/cyclin B1 kinase and triggers the cell to enter into mitosis. Since it is reported that a natural plant product curcumin can induce a similar G2/M arrest in human colorectal cancer lines HCT-116 (p53+/+), HCT-116 (p53 $-/-$ ), and HCT-116 (p21-/-) by regulating cdc2/cyclin B1 kinase activity [32], we investigated the expression of cyclin B1 and phosphorylated-cdc2 (Tyr15) in A549 cells treated with $\mathrm{C} 1$. As shown in Fig. 3e, the expression of cyclin $\mathrm{B} 1$ was increased after $\mathrm{C} 1$ treatment for $12 \mathrm{~h}$, while $\mathrm{C} 1$ decreased the phosphorylation of $\mathrm{cdc} 2$. These results suggest that cdc2/cyclin B1 kinase is activated after $\mathrm{C} 1$ treatment and that $\mathrm{C} 1$ treatment induces mitotic arrest rather than G2 arrest. In line with these results, the expression of phosphorylated-histone H3 (Ser10), a marker of mitotic cells, was observed in A549 cells treated with C1 (Fig. 3e). Furthermore, the analysis of nuclear morphology showed the increase of mitotic cells by $\mathrm{C} 1$ treatment (Additional file 3: Figure S3). Taken together, these results indicate that $\mathrm{C} 1$ induces mitotic arrest. 


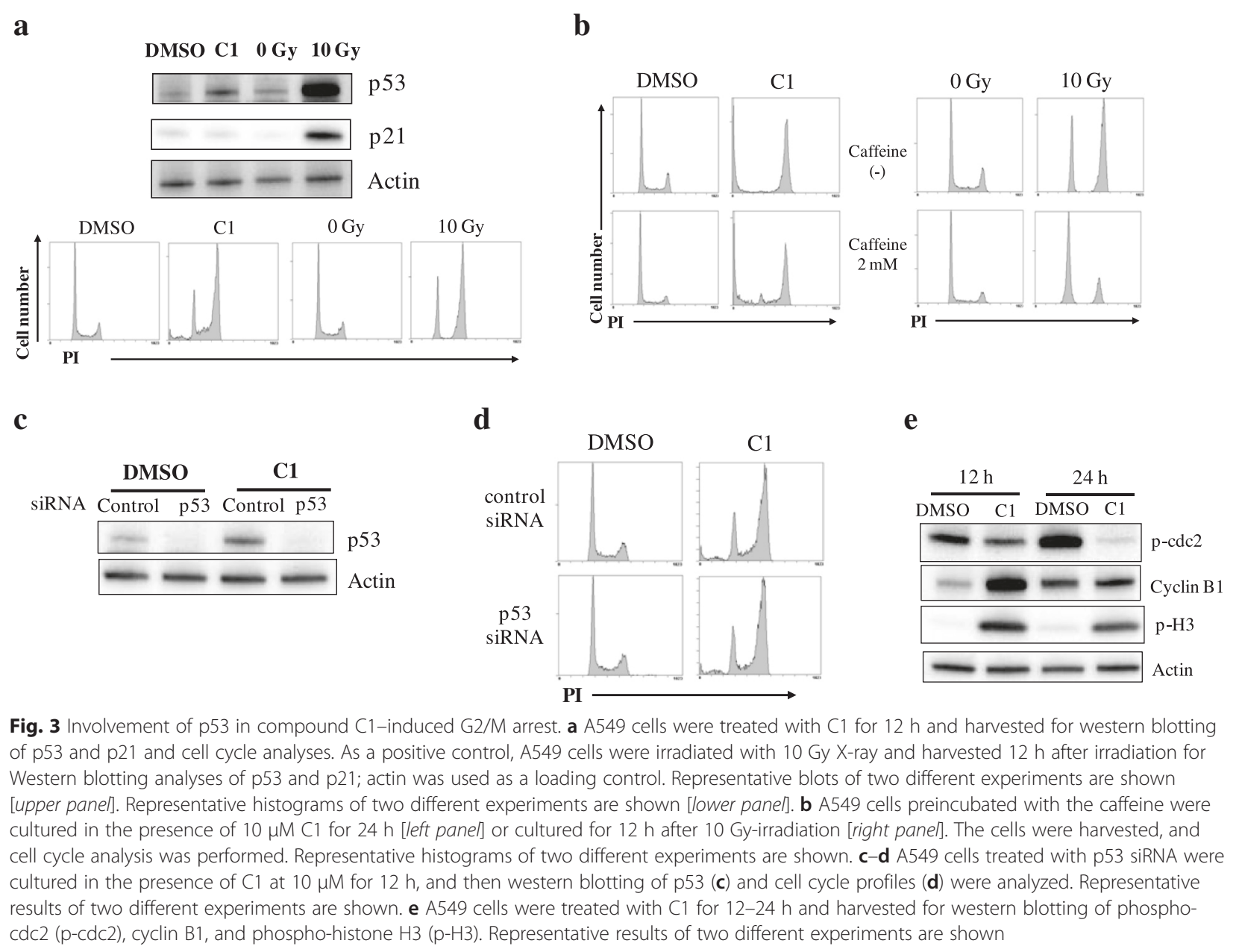

\section{Mesogenic compounds cause apoptosis}

To further verify the cytotoxic effects of our mesogenic compounds, we estimated apoptosis by sub-G1 fraction or annexin V-FITC and PI staining. As shown in Fig. 4a, treatment with $\mathrm{C} 1-\mathrm{C} 5$ increased the sub-G1 fraction, which is one of the hallmarks of apoptosis, in all NSCLC cell lines. Furthermore, $\mathrm{C} 1-\mathrm{C} 5$ induced annexin $\mathrm{V}(+)$ / $\mathrm{PI}(-)$ and/or $\mathrm{V}(+) / \mathrm{PI}(+)$ dead cells (Fig. 4b). These results indicate that mesogenic compounds carrying $p$ terphenyl with terminal alkoxyl and hydroxyl groups induce cell death, including apoptotic death, in NSCLC cells regardless of p53 status.

\section{Involvement of caspase in mesogenic compound-induced cell death}

Because caspase- 3 is a key effector protease responsible for DNA fragmentation during apoptosis, caspase-3 activation was examined. The expression of active caspase- 3 was approximately $20 \%$ higher in A549 cells treated with $\mathrm{C} 1$ for $48 \mathrm{~h}$ or $\mathrm{C} 2$ for $72 \mathrm{~h}$ than in the control cells, and this expression was reduced in the presence of the pan-caspase inhibitor Z-VAD-fmk (Fig. 5a). In line with the reduction of active caspase- 3 expression, treatment with Z-VAD-fmk decreased C1- and C2-induced sub-G1 fractions in A549 cells (Fig. 5b). Furthermore, C1- and C2-induced active caspase-3 expression and sub-G1 fractions in p53-null H1299 cells were decreased by ZVAD-fmk (Fig. 5c and d). Similar results were observed for C3-C5 treatment (data not shown). These results indicate that mesogenic compounds induce caspasemediated cell death independent of p53.

\section{Mesogenic compounds induce Fas-mediated cell death}

Since the executioner caspase- 3 can be activated by an extrinsic (capase-8) and/or an intrinsic pathway (capsase-9), we analyzed the expression of caspase- 8 and -9 in A549 cells treated with $\mathrm{C} 1$ and C2. As shown in Fig. 6a, C1 and C2 induced both cleaved caspase- 8 and cleaved caspase- 9 expression. We next investigated the involvement of Fas in cell death induced by our compounds because Fas induces caspase-mediated cell death [33]. As shown in Fig. 6b, Fas expression in A549 cells 


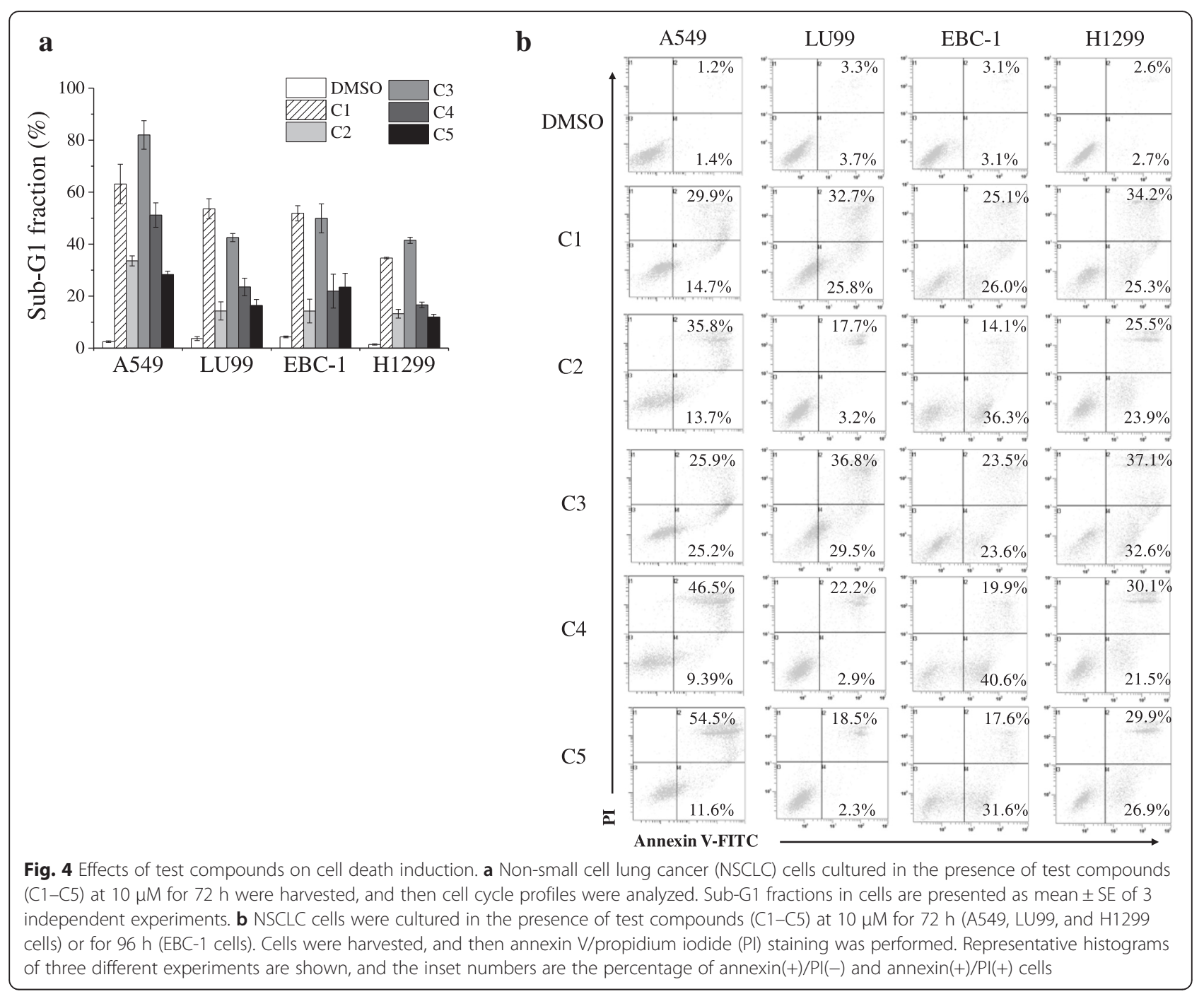

treated with $\mathrm{C} 1$ for $48 \mathrm{~h}$ was approximately 2 -fold higher than that in control cells. Furthermore, C1-induced cell death was significantly prevented by treatment with the Fas/Fas ligand antagonist kp7-6 [34] (Fig. 6c), indicating that $\mathrm{C} 1$ induces Fas-mediated cell death. Similarly, treatment with $\mathrm{C} 2$ increased Fas expression and $\mathrm{C} 2$-induced cell death was also decreased by kp7-6 (Fig. 6b and c). These results suggest that 3-ring compounds carrying terminal alkoxyl and hydroxyl groups may possess structurally important features for Fas-mediated cell death that are independent of the central pyrimidine moiety.

\section{Involvement of DNA damage-signaling pathway in mesogenic compound-induced cell death}

Since a number of chemotherapeutic drugs cause cytotoxicity through DNA damage [35], we investigate whether mesogenic compounds induce cell death through DNA damage. The serine/threonine protein kinase ATM plays key role in DNA damage response such as DNA repair, cell cycle arrest, and apoptosis [6]. Following DNA damage, ATM activates itself by autophosphorylation at Ser1981 [36]. Once activated, ATM phosphorylates numerous substrates involving in DNA damage response such as p53 and checkpoint kinases [6]. As shown in Fig. 7a, the phosphorylation of ATM at Ser1981 was increased in A549 cells treated with C1 and $\mathrm{C} 2$ as well as irradiation. Furthermore, treatment with caffeine significantly decreased the compounds-induced cell death (Fig. 7b). These results suggest that mesogenic compounds induce cell death through DNA damagesignaling pathway.

We next investigated whether p53 involves in the compounds-induced cell death in A549 cells. Although knockdown of p53 decreased the C1- and C2-induced p53 protein expression in A549 cells (Fig. 7c), it did not decreased those compounds-induced cleaved caspases-3 expression and cell death (Fig. 7c and d), thus suggesting that mesogenic compounds induce cell death through 


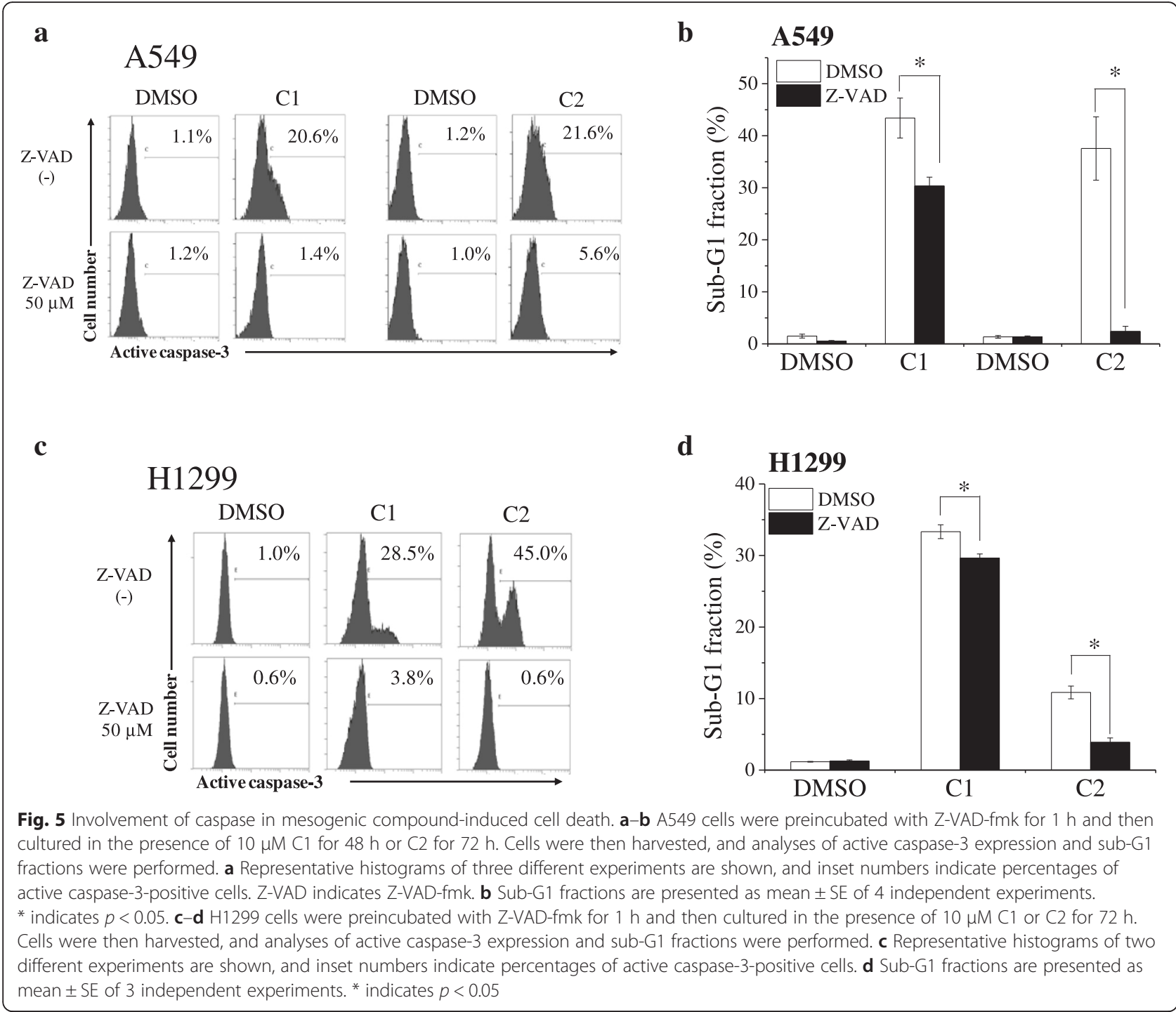

DNA damage-signaling pathway, but it is independent of $\mathrm{p} 53$.

\section{Cytotoxic effects of compounds in normal human fibroblast WI-38 cells}

In further experiments, we investigated whether our mesogenic compounds suppress the growth of WI-38 normal human fibroblast cells. As shown in Fig. 8a, C1 and $\mathrm{C} 3$, which carry a pyrimidine at the center of the core, dramatically suppressed WI-38 cell. In contrast, no cell growth suppression of WI-38 cells was observed with compounds $\mathrm{C} 2, \mathrm{C} 4$, and $\mathrm{C} 5$. The cell cycle analyses showed that compounds $\mathrm{C} 1$ and $\mathrm{C} 3$ induced G2/M arrest in WI-38 cells as well as NSCLC cells (Fig. 8b).

We next examined whether the alkyl chain length modulates cytotoxicity against WI-38 cells. Compound $\mathrm{C} 1$, which has a 6-carbon alkyl chain, caused the largest effect (Fig. 8c). Although compounds with 4- or 5- carbon alkyl chains dramatically suppressed the growth of NSCLC cells (Fig. 1f), those compounds showed only moderate cytotoxicity against WI-38 cells (approximately $40 \%$ inhibition; Fig. 8c).

\section{Discussion}

In this study, we investigated the cytotoxic effects of mesogenic compounds on human NSCLC cells and showed their corresponding structure-activity relationships. First, we demonstrated that 3-ring compounds carrying terminal alkyl and hydroxyl groups had superior cytotoxic effects against NSCLC cells, regardless of p53 status. Furthermore, we showed that these compounds affect cell cycle regulation lead to induction of apoptosis. In brief, compounds $\mathrm{C} 1$ and $\mathrm{C} 3$, which have a pyrimidine at the center of the core, induced caspase-mediated cell death following G2/M arrest, while compounds without a pyrimidine at the center 
a

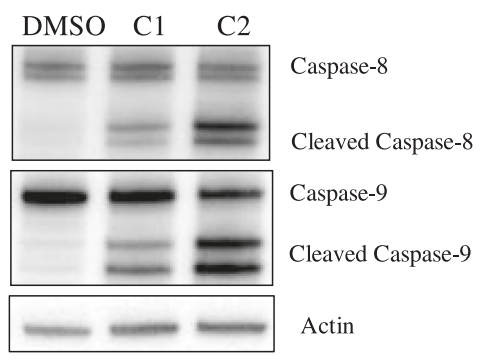

c

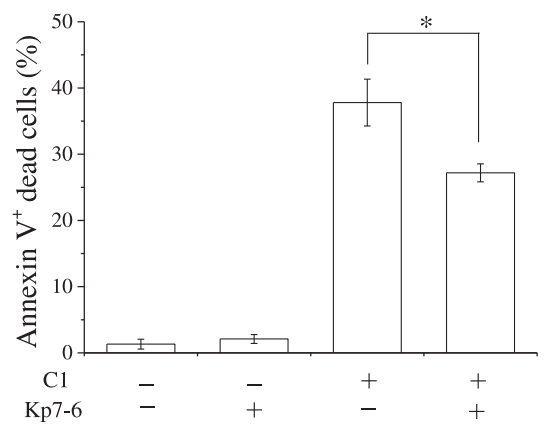

b
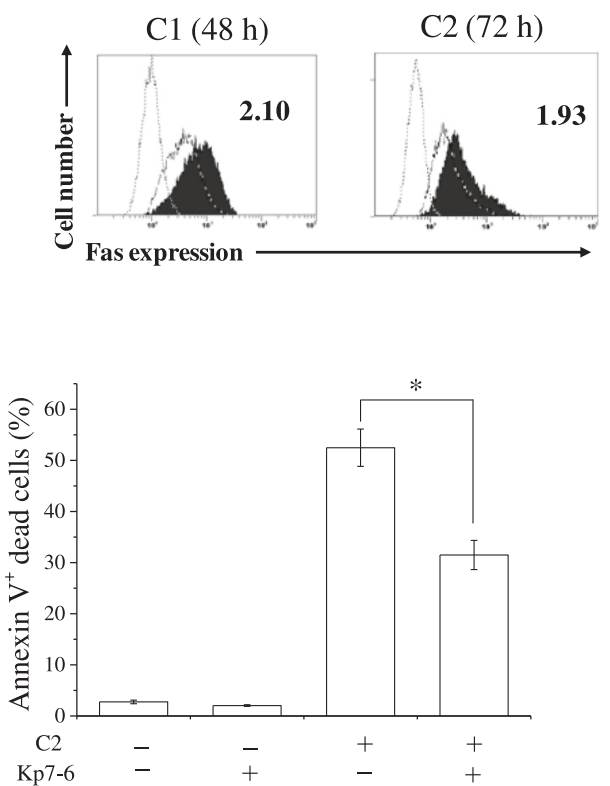

Fig. 6 Involvement of Fas in compound-induced cell death of A549 cells. a A549 cells were treated with C1 or C2 for 72 h and harvested for western blotting of caspase-8 and caspase-9. Representative results of two different experiments are shown. $\mathbf{b}$ A549 cells cultured in the presence of $10 \mu \mathrm{M} \mathrm{C1}$ for $48 \mathrm{~h}$ or C2 for $72 \mathrm{~h}$ were harvested, and cell surface Fas expression was analyzed. Representative histograms of three different experiments are shown. The dotted line histogram indicates cells stained with isotype control. The broken line and filled gray histograms indicate Fas expression in cells treated with vehicle and compound, respectively. Inset numbers indicate mean fluorescence intensities relative to the vehicle control. c A549 cells were preincubated with the Fas/Fas ligand antagonist kp7-6 and were cultured in the presence of $10 \mu \mathrm{M} \mathrm{C1} \mathrm{for} 48 \mathrm{~h}$ [left panel] or C2 for $72 \mathrm{~h}$ [right panel]. Cells were harvested and annexin V/propidium iodide staining was performed. Percentages of annexin $\mathrm{V}(+)$ cells are presented as the mean $\pm \mathrm{SE}$ of 3 independent experiments; ${ }^{*}$ indicates $p<0.05$

of the core $(\mathrm{C} 2, \mathrm{C} 4$, and $\mathrm{C} 5)$ induced caspase-mediated cell death following $\mathrm{G} 1$ arrest in a p53-independent manner.

$\log \mathrm{P}$ is an estimate of a compound's overall lipophilicity, which contributes to solubility and permeability through biological membranes; there are some reports that $\log \mathrm{P}$ is a determinant factor in the anticancer effects of some compounds [37, 38]. Supek et al. reported that the optimum $\log \mathrm{P}$ of crown ether compounds is approximately at 5.5 for anticancer effects [38]. In the present study, $\log \mathrm{P}$ values of our 3 -ring mesogenic compounds showing cytotoxicity $(\mathrm{C} 1-\mathrm{C} 5$ and compounds with 4- or 5-carbon alkyl chains) ranged from 4.84 to 6.38 in NSCLC cells. Interestingly, the $\log$ P value of 3ring compounds increased with alkyl chain lengths (the $\log \mathrm{P}$ values of compound with 4-, 5-, 6-, 8-, and 10carbon alkyl chains are 4.84, 5.26, 5.68, 6.52, and 7.36, respectively), and compounds with alkyl chain lengths exceeding six carbons showed lower cytotoxicity. Therefore, the lower cytotoxity of those compounds might be explained by their high lipophilicity. In contrast, compound with 4-carbon alkyl chains showed a strong cytotoxicty at $10 \mu \mathrm{M}$ (Fig. 1f), although its $\log \mathrm{P}$ value (4.84) was lower than the other cytotoxic compounds. However, the $\mathrm{IC}_{50}$ value of this compound in our previous work was approximately $5.5 \mu \mathrm{M}$ [22], which was higher than that of $\mathrm{C} 1$ with 6 -carbon alkyl chains $(1.9 \mu \mathrm{M})$. These results suggest that the relatively low lipophilicity also results in low cytoxicity.

We demonstrated that $\mathrm{C} 1$ can induce mitotic arrest followed by cell death, thus suggesting that $\mathrm{C} 1$ has potential to function as antimitotic agent. Some chemotherapeutic agents targeting mitosis are clinically used or currently developed for cancer treatment [39-41]. For example, vinca alkaloids (vincrstine, vinblastine, and vindesine) or taxanes (paclitaxel and docetaxel) inhibit mitosis by disrupting microtubule dynamics [42]. In addition, the inhibition of mitotic-specific kinases (e.g., polo-like kinase 1 and aurora kinases) involving in spindle formation and mitotic checkpoint results in atimitotic effect [43]. Therefore, it is possible that $\mathrm{C} 1$ affects the microtubules or the mitosic-specific kinases, although we need to investigate it in future analyses.

The present study showed that 3-ring compounds carrying terminal alkyl and hydroxyl groups induced caspase-mediated cell death independent of p53. We also showed that Fas mediates the cell death induced by compounds $\mathrm{C} 1$ and $\mathrm{C} 2$. Ferreira et al. reported that anticancer drugs such as cisplatin, gemcitabine, topotecan, 


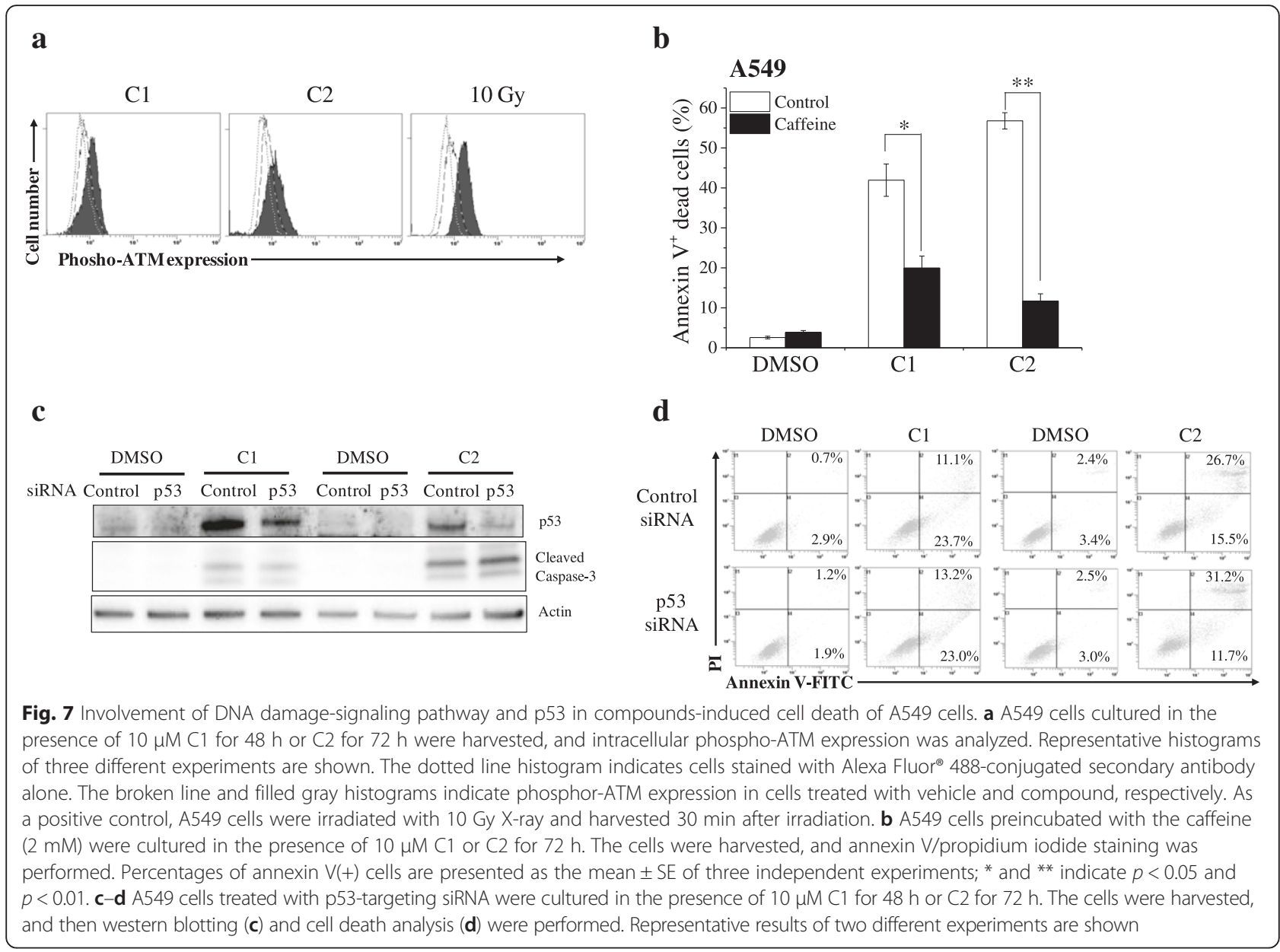

and paclitaxel, which are typically used in lung cancer treatment, induce apoptosis without using the Fas/Fas ligand signaling pathway [44]. Therefore, it is likely that there will be synergistic effects between our mesogenic compounds and these anticancer drugs.

Compounds $\mathrm{C} 1$ and $\mathrm{C} 2$ increased the phosphorylation of ATM, and the cell death induced by those compounds was decreased by ATM/ATR inhibitor caffeine (Fig. 7a and $b)$. These results suggest that 3-ring compounds carrying terminal alkoxyl and hydroxyl groups may possess structurally important features for DNA damagesignaling pathway-mediated cell death that are independent of the central pyrimidine moiety. Although it is known that p53 is an important target of ATM and it plays key role in DNA damage-induced cell death [45-47], compounds $\mathrm{C} 1$ and C2 induced cell death in a p53-independent manner. There are several strategies that cells seem to employ to trigger p53independent DNA damage-induced apoptosis [46, 47]. For example, a p53 homolog p73 is implicated in it. Upon DNA damage, ATM/ATR increases the levels of p73 protein through the activation of transcriptional factor E2F1 [48]. As well as p53, p73 can induce apoptosis through death receptor pathway and mitochondrial apoptotic pathway [49, 50]. Furthermore, homeodomain-interacting protein kinase 2, a serine/ threonine protein kinase, also can trigger p53indepdent DNA damage-induced apoptosis [47, 51]. Therefore, it will be necessary to determine the involvement of those proteins in the compounds-induced cell death in future study.

Side effects are considerable for most anticancer drugs. Although $\mathrm{C} 1$ has potential to have a broad cytotoxic effect against NSCLC cells, it also showed strong cytotoxicity against WI-38 cells. Specifically, treatment with $\mathrm{C} 1$ and C3 caused G2/M arrest in WI-38 cells (Fig. 8b), potentially reflecting similar cell death mechanisms following G2/M arrest as those seen in NSCLC cells. However, derivatives of $\mathrm{C} 1$ with 4- or 5-carbon alkyl chain lengths showed more moderate cytotoxic effects against WI-38 cells while retaining dramatic cytotoxicity against NSCLC cells, suggesting that the modulation of alkyl chain length might improve the cancer-specific cytotoxicity of these mesogenic compounds. This may be due to the differences in cell membrane compositions and cell membrane permeability between cancer and normal 
$\mathbf{a}$

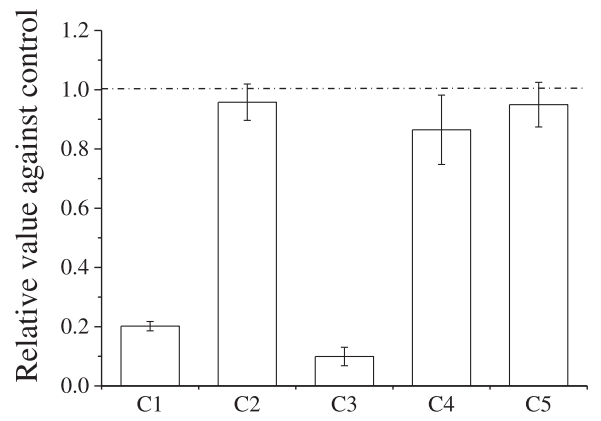

c

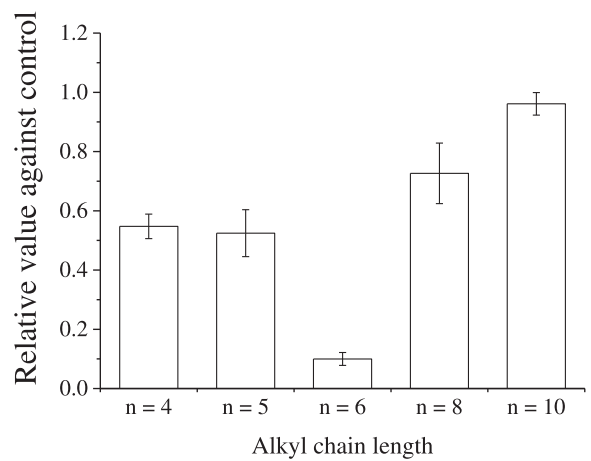

b

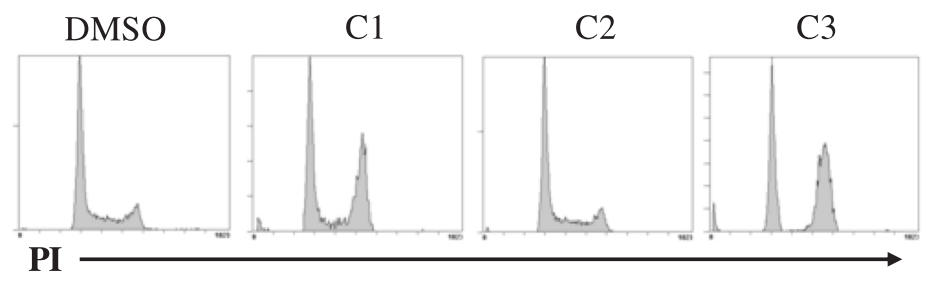

Fig. 8 Effects of the compounds on the growth of WI-38 cells. a WI-38 cells cultured in the presence of test compounds at $10 \mu \mathrm{M}$ for 3 days were harvested, and viable cells were counted using trypan blue exclusion assays. Data are presented as the mean \pm SE of four independent experiments. b WI-38 cells cultured in the presence of test compounds (C1, C2, and C3) at $10 \mu \mathrm{M}$ for $12 \mathrm{~h}$ were harvested, and then cell cycle profiles were analyzed. c Cytotoxic effects of compound C1 and its derivatives with varying alkyl chain lengths are shown. WI-38 cells cultured in the presence of test compounds at $10 \mu \mathrm{M}$ for 3 days were harvested, and viable cells were counted using trypan blue exclusion assays. Data are presented as the mean \pm SE of four independent experiments

cells $[52,53]$. On the other hand, compounds $\mathrm{C} 2, \mathrm{C} 4$, and $\mathrm{C} 5$ showed no significant growth-suppressive effects against the normal human fibroblast WI-38, which is promising for cancer-specific agents. The response to DNA damage varies depending on the cell type, and it is mentioned that fibroblasts are relatively resistant to DNA damage-induced apoptosis [45, 54]. That is why cytotoxic effect by $\mathrm{C} 2$ through DNA damage-signaling pathway might not be effective in human fibroblast WI38 cells. To further clarify cancer-specific cytotoxic effects of these compounds, the cytotoxicity against other cell types such as hematopoietic cells should be examined in future study.

\section{Conclusions}

In conclusion, this study demonstrated that not only the 3-ring structure with terminal alkyl and hydroxyl groups but also the alkyl chain lengths are structurally important for the cytotoxic effects of mesogenic compounds against human NSCLC cells. In addition, we showed that cell cycle arrest depended on the position of the pyrimidine, and that the cytotoxic effects in human lung-derived normal fibroblasts varied depending on not only the position of pyrimidine but also the terminal alkyl chain length. Although we need to verify whether the cytotoxic effects of these mesogenic compounds obtained in vitro study are effective in vivo, we believe that these structureactivity relationships will be helpful in the development of more effective and cancer-specific agents.

\section{Additional files}

Additional file 1: Figure S1. Dose response effects of test compounds on the growth of A549 cells. A549 cells cultured in the presence of compounds $\mathrm{C} 1$ and $\mathrm{C} 2$ at $0.75-12 \mu \mathrm{M}$ for 3 days were harvested, and viable cells were counted using trypan blue exclusion assays. Data are presented as the mean \pm SE of 3 independent experiments. (DOCX $60 \mathrm{~kb}$ )

Additional file 2: Figure S2. Effects of test compounds on cell cycle progression. Non-small cell lung cancer cells cultured in the presence of test compounds (C3-C5) at $10 \mu \mathrm{M}$ for 24-48 $\mathrm{h}$ were harvested, and then cell cycle profiles were analyzed. Representative histograms are shown. (DOCX $195 \mathrm{~kb}$ )

Additional file 3: Figure S3. Nuclear morphology of A549 cells treated with C1. A549 cells $\left(4.0 \times 10^{4}\right.$ cells) were grown on chamber slides II (IWAKI) overnight to allow adherence to the slides. After treatment with compound $\mathrm{C} 1$ for $12 \mathrm{~h}$, the cells were fixed with $4 \%$ formaldehyde for 
$30 \mathrm{~min}$ at room temperature. Fixed cells were washed with PBS $(-)$ permeabilized in $0.5 \%$ TritonX-100 for 5 min at $4{ }^{\circ} \mathrm{C}$, and washed with PBS(-). The slides were stained and mounted with VECTASHIELD ${ }^{\odot}$ Mounting Medium with DAPI (Vector Laboratories, Inc., Burlingame, CA, USA). Photographs of the cells were taken with an Olympus IX71 (Tokyo, Japan) and DP2-BSW software (Olympus). Representative results are shown. Arrow indicates mitotic cells. (DOCX 728 kb)

\section{Abbreviations}

ATM, ataxia telangiectasia mutated; ATR, ataxia telangiectasia and Rad-3 related; $C D$, cluster of differentiation; DMSO, dimethyl sulfoxide; $F B S$, fetal bovine serum; FITC, fluorescein isothiocyanate; $\mathrm{IC}_{50}, 50 \%$ inhibitory concentration; LC, liquid crystal; NSCLC, non-small cell lung cancer; PBS(-), $\mathrm{Ca}^{(2+)}$ - and $\mathrm{Mg}^{(2+)}$ - free phosphate-buffered saline; Pl, propidium iodide: Z-VAD-fmk, Z-Val-Ala-Asp (OMe)- $\mathrm{CH}_{2} \mathrm{~F}$

\section{Acknowledgments}

The authors would like to thank Enago (www.enago.jp) for the English language review.

\section{Funding}

This study received support from a Grant-in-Aid for Scientific Research (Grant Number JP25107702) on the Innovation Areas: "Fusion Materials" (Area no 22006) from MEXT, a Hirosaki University Grant for Exploratory Research by Young Scientists, and a Priority Research Grant for Young Scientists Designated by the President of Hirosaki University. This work was also partially supported by JSPS KAKENHI, Grant-in-Aid for Young Scientists (B; Grant Number JP25861053).

\section{Availability of data and material}

All data generated or analyzed during this study are included in this published article and its supplementary information files.

\section{Authors' contributions}

SF and HY performed the research, analyzed the data, and wrote the manuscript. AY and IK led the overall design of the study and edited the manuscript. All authors read and approved the final manuscript.

\section{Competing interests}

The authors declare that they have no competing interests.

\section{Consent for publication}

Not applicable.

\section{Ethics approval and consent to participate}

Not applicable.

\section{Author details}

'Department of Frontier Materials Chemistry, Graduate School of Science and Technology, Hirosaki University, 3 Bunkyo-cho, Hirosaki, Aomori 036-8561, Japan. ${ }^{2}$ Department of Radiation Science, Hirosaki University Graduate School of Health Sciences, 66-1 Hon-cho, Hirosaki, Aomori 036-8564, Japan.

Received: 29 December 2015 Accepted: 20 July 2016

Published online: 25 July 2016

\section{References}

1. Tsai MF, Wang CC, Chen JJ. Tumour suppressor HLJ1: A potential diagnostic, preventive and therapeutic target in non-small cell lung cancer. World J Clin Oncol. 2014:5:865-73.

2. Hida T, Ogawa S, Park JC, Park JY, Shimizu J, Horio Y, Yoshida K. Gefitinib for the treatment of non-small-cell lung cancer. Expert Rev Anticancer Ther. 2009;9:17-35

3. Jiang $\mathrm{H}$. Overview of gefitinib in non-small cell lung cancer: an Asian perspective. Jpn J Clin Oncol. 2009;39:137-50.

4. Park SY, Kim YM, Pyo H. Gefitinib radiosensitizes non-small cell lung cancer cells through inhibition of ataxia telangiectasia mutated. Mol Cancer. 2010;9:222.

5. Lakin ND, Jackson SP. Regulation of p53 in response to DNA damage. Oncogene. 1999;18:7644-55.
6. Roos WP, Kaina B. DNA damage-induced cell death: from specific DNA lesions to the DNA damage response and apoptosis. Cancer Lett. 2013;332: 237-48.

7. Moll UM, Wolff S, Speidel D, Deppert W. Transcription-independent proapoptotic functions of p53. Curr Opin Cell Biol. 2005;17:631-6.

8. Fan S, el-Deiry WS, Bae I, Freeman J, Jondle D, Bhatia K, Fornace Jr AJ, Magrath I, Kohn KW, O'Connor PM. p53 gene mutations are associated with decreased sensitivity of human lymphoma cells to DNA damaging agents. Cancer Res. 1994;54:5824-30.

9. Bunz F, Hwang PM, Torrance C, Waldman T, Zhang Y, Dillehay L, Williams J, Lengauer C, Kinzler KW, Vogelstein B. Disruption of p53 in human cancer cells alters the responses to therapeutic agents. J Clin Invest. 1999;104:263-9.

10. Rho JK, Choi YJ, Ryoo BY, Na II, Yang SH, Kim CH, Lee JC. p53 enhances gefitinib-induced growth inhibition and apoptosis by regulation of Fas in non-small cell lung cancer. Cancer Res. 2007:67:1163-9.

11. Huang S, Benavente S, Armstrong EA, Li C, Wheeler DL, Harari PM. p53 modulates acquired resistance to EGFR inhibitors and radiation. Cancer Res. 2011;71:7071-9.

12. Aurelio ON, Cajot JF, Hua ML, Khwaja Z, Stanbridge EJ. Germ-line-derived hinge domain p53 mutants have lost apoptotic but not cell cycle arrest functions. Cancer Res. 1998;58:2190-5.

13. Rowan S, Ludwig RL, Haupt Y, Bates S, Lu X, Oren M, Vousden KH. Specific loss of apoptotic but not cell-cycle arrest function in a human tumor derived p53 mutant. EMBO J. 1996;15:827-38.

14. Viktorsson $K$, De Petris $L$, Lewensohn $R$. The role of p53 in treatment responses of lung cancer. Biochem Biophys Res Commun. 2005;331:868-80.

15. Stewart DJ. Tumor and host factors that may limit efficacy of chemotherapy in non-small cell and small cell lung cancer. Crit Rev Oncol Hematol. 2010;75:173-234.

16. Stevenson CL, Bennett DB, Lechuga-Ballesteros D. Pharmaceutical liquid crystals: the relevance of partially ordered systems. J Pharm Sci. 2005;94:1861-80.

17. Cervin C, Vandoolaeghe P, Nistor C, Tiberg F, Johnsson M. A combined in vitro and in vivo study on the interactions between somatostatin and lipidbased liquid crystalline drug carriers and bilayers. Eur J Pharm Sci. 2009;36: 377-85.

18. Wang M, Gartel AL. Micelle-encapsulated thiostrepton as an effective nanomedicine for inhibiting tumor growth and for suppressing FOXM1 in human xenografts. Mol Cancer Ther. 2011;10:2287-97.

19. Terasawa R, Fukushi Y, Monzen S, Miura T, Takahashi K, Yoshizawa A, Kashiwakura I. The promoting activity on human megakaryocytopoiesis and thrombopoiesis by liquid crystal-related compounds. Biol Pharm Bull. 2009:32:976-81.

20. Takahashi Y, Hazawa M, Takahashi K, Nishizawa A, Yoshizawa A, Kashiwakura I. Suppressive effects of liquid crystal compounds on the growth of the A549 human lung cancer cell line. Invest New Drugs. 2011;29:659-65.

21. Fukushi Y, Hazawa M, Takahashi K, Yoshizawa A, Kashiwakura I. Liquid crystal-related compound-induced cell growth suppression and apoptosis in the chronic myelogenous leukemia K562 cell line. Invest New Drugs. 2011 29:827-32.

22. Wakasaya T, Yoshino H, Fukushi Y, Yoshizawa A, Kashiwakura I. A liquid crystal-related compound induces cell cycle arrest at the G2/M phase and apoptosis in the A549 human non-small cell lung cancer cell line. Int J Oncol. 2013:42:1205-11.

23. Fukushi Y, Yoshino H, Ishikawa J, Sagisaka M, Kashiwakura I, Yoshizawa A. Synthesis and anticancer properties of phenyl benzoate derivatives possessing a terminal hydroxyl group. J Mater Chem B. 2014;2:1335-43.

24. Yoshino $H$, Saitoh $T$, Kozakai M, Kashiwakura I. Effects of ionizing radiation on retinoic acid-inducible gene-l-like receptors. Biomed Rep. 2015;3:59-62.

25. Yanai H. Statcel-the useful add-in software forms on Excel. 3rd ed. Tokyo: OMS; 2011.

26. Arnott JA, Kumar R, Planey SL. Lipophilicity indices for drug development. J Appl Biopharm Pharmacokinet. 2013;1:31-6.

27. Taylor WR, Stark GR. Regulation of the G2/M transition by p53. Oncogene. 2001;20:1803-15.

28. Sarkaria JN, Busby EC, Tibbetts RS, Roos P, Taya Y, Karnitz LM, Abraham RT Inhibition of ATM and ATR kinase activities by the radiosensitizing agent, caffeine. Cancer Res. 1999;59:4375-82

29. Morgan DO. Cyclin-dependent kinases: engines, clocks, and microprocessors. Annu Rev Cell Dev Biol. 1997;13:261-91.

30. Jin P, Hardy S, Morgan DO. Nuclear localization of cyclin B1 controls mitotic entry after DNA damage. J Cell Biol. 1998;141:875-85. 
31. Stark GR, Taylor WR. Control of the G2/M transition. Mol Biotechnol. 2006;32:227-48.

32. Jaiswal AS, Marlow BP, Gupta N, Narayan S. Beta-catenin-mediated transactivation and cell-cell adhesion pathways are important in curcumin (diferuylmethane)-induced growth arrest and apoptosis in colon cancer cells. Oncogene. 2002;21:8414-27.

33. Kaufmann T, Strasser A, Jost PJ. Fas death receptor signalling: roles of Bid and XIAP. Cell Death Differ. 2012;19:42-50.

34. Hasegawa A, Cheng X, Kajino K, Berezov A, Murata K, Nakayama T, Yagita H, Murali R, Greene MI. Fas-disabling small exocyclic peptide mimetics limit apoptosis by an unexpected mechanism. Proc Natl Acad Sci U S A. 2004; 101:6599-604

35. Cheung-Ong K, Giaever G, Nislow C. DNA-damaging agents in cancer chemotherapy: serendipity and chemical biology. Chem Biol. 2013;20:648-59.

36. Bakkenist CJ, Kastan MB. DNA damage activates ATM through intermolecular autophosphorylation and dimer dissociation. Nature. 2003;421:499-506.

37. Maliepaard M, de Mol NJ, Janssen LH, van der Neut W, Verboom W, Reinhoudt DN. Role of lipophilicity in the in vitro antitumour activity of a series of new mitosene compounds. Anticancer Drug Des. 1992;7:415-25.

38. Supek F, Ramljak TŠ, Marjanović M, Buljubašić M, Kragol G, llić N, Smuc T, Zahradka D, Mlinarić-Majerski K, Kralj M. Could LogP be a principal determinant of biological activity in 18-crown-6 ethers? Synthesis of biologically active adamantane-substituted diaza-crowns. Eur J Med Chem. 2011:46:3444-54.

39. Jackson JR, Patrick DR, Dar MM, Huang PS. Targeted anti-mitotic therapies: can we improve on tubulin agents? Nat Rev Cancer. 2007:7:107-17.

40. Manchado E, Guillamot M, Malumbres M. Killing cells by targeting mitosis. Cell Death Differ. 2012;19:369-77.

41. Marzo I, Naval J. Antimitotic drugs in cancer chemotherapy: promises and pitfalls. Biochem Pharmacol. 2013;86:703-10.

42. Kavallaris M. Microtubules and resistance to tubulin-binding agents. Nat Rev Cancer. 2010;10:194-204.

43. Musacchio A, Salmon ED. The spindle-assembly checkpoint in space and time. Nat Rev Mol Cell Biol. 2007;8:379-93.

44. Ferreira CG, Tolis C, Span SW, Peters GJ, van Lopik T, Kummer AJ, Pinedo HM, Giaccone G. Drug-induced apoptosis in lung cnacer cells is not mediated by the Fas/FasL (CD95/APO1) signaling pathway. Clin Cancer Res. 2000;6:203-12.

45. Norbury CJ, Zhivotovsky B. DNA damage-induced apoptosis. Oncogene. 2004;23:2797-808

46. Roos WP, Kaina B. DNA damage-induced cell death by apoptosis. Trends Mol Med. 2006;12:440-50.

47. Bitomsky N, Hofmann TG. Apoptosis and autophagy: Regulation of apoptosis by DNA damage signalling - roles of p53, p73 and HIPK2. FEBS J. 2009;276:6074-83.

48. Urist M, Tanaka T, Poyurovsky MV, Prives C. p73 induction after DNA damage is regulated by checkpoint kinases Chk1 and Chk2. Genes Dev. 2004:18:3041-54

49. Ramadan S, Terrinoni A, Catani MV, Sayan AE, Knight RA, Mueller M, Krammer PH, Melino G, Candi E. p73 induces apoptosis by different mechanisms. Biochem Biophys Res Commun. 2005;331:713-7.

50. Allocati N, Di llio C, De Laurenzi V. p63/p73 in the control of cell cycle and cell death. Exp Cell Res. 2012;318:1285-90.

51. Hofmann TG, Glas C, Bitomsky N. HIPK2: A tumour suppressor that controls DNA damage-induced cell fate and cytokinesis. Bioessays. 2013;35:55-64.

52. Sok M, Sentjurc M, Schara M. Membrane fluidity characteristics of human lung cancer. Cancer Lett. 1999;139:215-20.

53. Mullin JM, Laughlin KV, Ginanni N, Marano CW, Clarke HM, Peralta Soler A. Increased tight junction permeability can result from protein kinase $C$ activation/translocation and act as a tumor promotional event in epithelial cancers. Ann N Y Acad Sci. 2000:915:231-6.

54. Zinkel SS, Hurov KE, Ong C, Abtahi FM, Gross A, Korsmeyer SJ. A role for proapoptotic BID in the DNA-damage response. Cell. 2005;122:579-91.

\section{Submit your next manuscript to BioMed Central and we will help you at every step:}

- We accept pre-submission inquiries

- Our selector tool helps you to find the most relevant journal

- We provide round the clock customer support

- Convenient online submission

- Thorough peer review

- Inclusion in PubMed and all major indexing services

- Maximum visibility for your research

Submit your manuscript at www.biomedcentral.com/submit
Biomed Central 